\title{
Effects of Teacher Participation in in-service Training on Achievement in Kenya Certificate of Primary Examination in Kirinyaga County, Kenya
}

\author{
Damaris Kariuki: kariuki.damaris@ku.ac.ke, Kenyatta University Nairobi, Kenya \\ Florence Itegi: itegi.florence@ku.ac.ke, Kenyatta University Nairobi, Kenya \\ Norbert Ogeta: Ogeta.norbert@ku.ac.ke, Kenyatta University Nairobi, Kenya
}

Accepted February 2020

Published November 2020

\begin{abstract}
Teacher Professional Development is a key component of educational reforms across the world due to its effects on teacher effectiveness and learner outcomes. Teachers engage in different professional development programs to improve learner achievements. However, the effects of teacher participation in in-service courses on learners' achievement have come under scrutiny due to persistent low learning outcomes. The study adopted convergent parallel mixed methods approach design. A sample of 194 teachers in 68 public and private primary schools was selected using stratified random and purposive sampling. Data collection instruments were questionnaires and focus group discussion guide. Data were analyzed using descriptive and inferential statistics. The study established that teacher participation in formal training programs had statistically insignificant effects on Kenya Certificate of Primary Examination achievement indicating that other factors like individualized attention to learners, prompt marking and revision of tests as well as supervision of teaching and learning contributed greatly. The in-service courses were found to be short term and infrequent. The study recommends engagement of teachers in continuous and frequent professional development activities and establishment of school infrastructure to support daily collaborative teacher professional development activities at the school level.
\end{abstract}

Key words: In-service Training, Teacher Professional Development, Learner Achievement

\section{Introduction}

Darling-Hammond, Hyler and Gardner (2017) define effective professional development as professional learning that is structured resulting in changes in teacher practices and improvements in student learning outcomes. Darling-Hammond (2000) notes that teachers are the most crucial of the school related factors that affect learner achievement. Pre-service teacher training alone is not capable of preparing teachers for lifelong teaching and learning challenges, which lie ahead in this rapidly changing $21^{\text {st }}$ century society. Therefore, there is need for continuous professional development. Darling-Hammond (2009) further asserts that quality teacher professional development has a positive impact on learner achievement.

World Bank (2010) notes that researchers, educators and policy makers are convinced that pre- 
service training is not yielding the expected results and therefore resources would be better utilized if directed to effective professional development. The Teachers' Service Commission (TSC) is cognizant of this fact and therefore developed the Teacher Performance Appraisal and Development (TPAD) tool in 2014 with professional development as one of the teacher competency areas (TSC ACT, 2012). The major goal of any teacher professional development program is its impact on learner achievement, for example, Strengthen Mathematics and Science Education (SMASE). In America, the No Child Left Behind (NCLB) Act (2001) focused on provision of high quality professional development for teachers across all states in order to improve student academic gains. The Act had a provision for systematic review of evidence on the effects of professional development in student learning. Teachers engage in different professional activities with a bid to improve their practice and learner outcomes. For instance, in Kirinyaga County, teachers were engaged in formal college programs resulting in higher academic qualifications as well as courses like SMASE. Professional development takes place in various forms ranging from traditional approaches (inservice courses like workshops) to modern approaches (e.g. communities of practice). However, research shows conflicting results on the effects of different professional development approaches on learner achievement.

Kukla-Acevedo (2009) and Harris and Sass (2011) note that there is a lot of literature on the relationship between pre-service training and student achievement and not on the effectiveness of professional development in influencing in-service teacher quality, and achievement. This study, however, sought to focus on effects of teacher professional development i.e. formal training programs (academic advancement and in-service courses) on KCPE achievement.

This study focused on teacher attendance to in-service courses as well as their improved academic qualification and the effects of these on KCPE achievement. Studies have established the role of in-service training on achievement. Essel, Badu, Owusu-Boateng, and Saah, (2009) explored the positive impact of teacher engagement in in-service training and achievement. Harris and Sass (2011) found a positive and significant correlation between teacher in-service training and learner achievement. Cohen and Hill (2000) had also found a positive relationship between teachers participating in student curriculum workshops and students' math scores. Seminars and workshops often help to change teachers' beliefs and attitudes. The expectations were that once teachers changed their beliefs and practices, their classroom practices and behaviors would also change (Clarke and Hollingsworth, 2002).

However, Bezzina (2001) claimed that professional development which takes place outside of school is out of context with the learning needs of teachers. Joyce and Showers (2002) also showed that workshops alone have less than a 5\% chance of changing teacher classroom practices. Literature notes the weaknesses of traditional forms of in-service training and one shot workshops and the need to engage teachers in a richer variety of professional development activities and modes of delivery (Brown-Easton, 2004; Feiman-Nemser 2001; Guskey 2000). Supovitz and Turner (2000) found out that contact hours of professional development had a positive relationship with teachers' outcomes, like attitude, preparedness, and teaching practice.

The duration and frequency of professional development programs are critical aspects that have an 
influence on the impact of the program. Desimone (2009) avers that for any professional development program to be effective, it must be continuous and long term. There was need therefore to establish the duration and frequency of the programs that teachers had attended. Darling-Hammond et al., (2009) and Desimone (2009) point out to the importance of sustained duration for professional development to be effective.

There have also been conflicting results on the effects of teacher improved academic qualifications and learner achievement. Buddin and Gema's study in 2009 in Los Angeles elementary schools found a relationship between teacher academic qualifications and achievement. Clotfelter, Ladd, and Vigdor (2008), on the other hand, concluded that teachers in early grades who got a master's degree after five years of teaching had a negative effect on learner achievement. Kimani, Kara and Njagi (2013) established that teachers' academic qualifications above the first degree did not lead to improved competence of teaching at the secondary school level. It was imperative therefore to investigate the effects of teacher participation in in-service programs and academic qualifications in the background of performance disparities between public and private schools in Kirinyaga County.

\section{Statement of the problem}

Quality teacher professional development has positive effects on learner achievement. Teacher professional development has been adopted by many countries across the world as a key component of educational reforms with a view to improving teacher quality and learner achievement. Despite teacher engagement in professional development activities, low learner achievement in national examination at primary school continues to be witnessed (EFA, Global monitoring Report, 2013/14). Teachers are engaged in different forms of professional development activities. However, the effects of teacher participation in in-service courses and improved academic qualifications on learner achievement has not been established particularly in Kirinyaga County where performance disparities are glaring between public and private primary schools.

\section{Objective of the study}

The study was guided by the following objectives:

i. To find out the level of teacher academic qualifications.

ii. To establish the forms of in-service programs teacher were engaged in.

iii. To find out the frequency and duration of the in-service courses attended.

iv. To find out the effects of teacher academic qualifications and attendance to in-service courses on KCPE achievement.

\section{Literature Review}

Literature was reviewed with regard to academic qualifications of teachers and in-service courses. Improved teacher qualifications are often positively linked with increased student achievement particularly in mathematics. According to Aaronson, Barrow, \& Sanders (2003) and Wenglisnky (2002), teacher completion of an undergraduate or graduate major in mathematics is associated with higher student achievement in high school and middle school. Wenglisnky (2000) had also found similar results in science. The effects associated with a teacher's possession of an advanced degree are strikingly counter-intuitive, considering the salary incentives given to teachers to pursue graduate degrees. However, there is no significant benefit for students of teachers with advanced 
degrees like Master. In fact, studies indicate that teachers with master's degrees and beyond may negatively influence their students' achievement (Clotfelter, Ladd, \&Vigdor, 2006; Rowan, Correnti, \& Miller, 2002).

Betts, Zau, and Rice (2003) found a positive but insignificant effects for middle school mathematics achievement when teachers hold master's degrees. On the other hand, Hanushek, Kain, O'Brien, and Rivkin (2005) did not find any association between teachers holding master's degrees and fourth to eighth-grade students' mathematics achievement in Texas. This study sought to find out the effects of academic qualifications after pre service training and their effects on KCPE achievement.

This study focused on teacher participation in formal training programs which comprised teacher academic progress and attendance to in-service courses. According to Ball and Cohen (1999) singleshot, one-day workshops often make teacher professional development "intellectually superficial, disconnected from deep issues of curriculum and learning, fragmented, and noncumulative. There is need therefore, to engage teachers in a richer variety of professional development activities and modes of delivery (Feiman-Nemser 2001; Guskey 2000). Fullan (2007) is of the view that external approaches outside the school are not powerful enough, specific enough, or sustained enough to change the culture of the classroom and school.

Cohen and Hill (2000) investigated the association between teachers' participation in student curriculum workshops and changes in teachers' practice and student achievement. They used regression analysis and found a positive relationship between teachers participating in student curriculum workshops and students' math scores. This study investigated the effects of teacher participation in formal training programs for academic qualifications and in-service courses on KCPE achievement.

According to Fullan (2009), only $10 \%$ to $20 \%$ of American teachers engage in meaningful professional development while $90 \%$ of them participate in professional development consisting mainly of one day or short-term workshops and conferences. In Parise and Spillane's (2010) study on school staff members in 30 American elementary schools showed that teachers appreciate formal further education that is directly connected to teaching in school. This study sought to investigate the level of teacher engagement in workshops and seminars and their effects on KCPE achievement. This is because teachers have been attending in-service training activities provided by the government and other development partners, publishers, religious organizations and other providers. The effects of these formal training activities on KCPE achievement in Kirinyaga is however not clear. Bezzina (2001) claimed that professional development which takes place outside of schools is out of context with the learning needs of teachers. Joyce and Showers (2002) also showed that workshops alone have less than a 5\% chance of changing teacher classroom practices. Kukla-Acevedo (2009) and Harris and Sass (2011) note that there is a lot of literature on the relationship between pre-service training and student achievement and not on the effectiveness of professional development in influencing in-service teacher quality, and achievement. This study, however, sought to focus on effects of teacher professional development in the form of formal training for academic advancement and in-service courses on KCPE achievement. A study done by Feng and Sass (2010) found that in-service professional development for teachers has little effects on their ability to increase the achievement gains of students. 


\section{Research Design}

The study adopted convergent parallel mixed methods research design where both quantitative and qualitative data was collected within the same phase. The design was appropriate as it gave a comprehensive view of the phenomena under investigation. Stratified random sampling technique was applied in which the school categories formed strata i.e. public and private and proportional allocation was used for each stratum. The target population was 1705 class eight teachers in 341 public and private school in Kirinyaga County. Stratified random sampling was used to obtain $10 \%$ of the teachers yielding 170 respondents. Purposive sampling was used to select two public and private schools i.e. performing (300 marks and above), non-performing (250 and below) where focus group discussions were conducted. The total sample size was 194. Data were collected using teacher questionnaires and focus group discussion guides. A total of four focus group discussions were conducted each with six participants giving a total of 24. Quantitative data was analyzed using descriptive and inferential statistics while qualitative data was analyzed thematically.

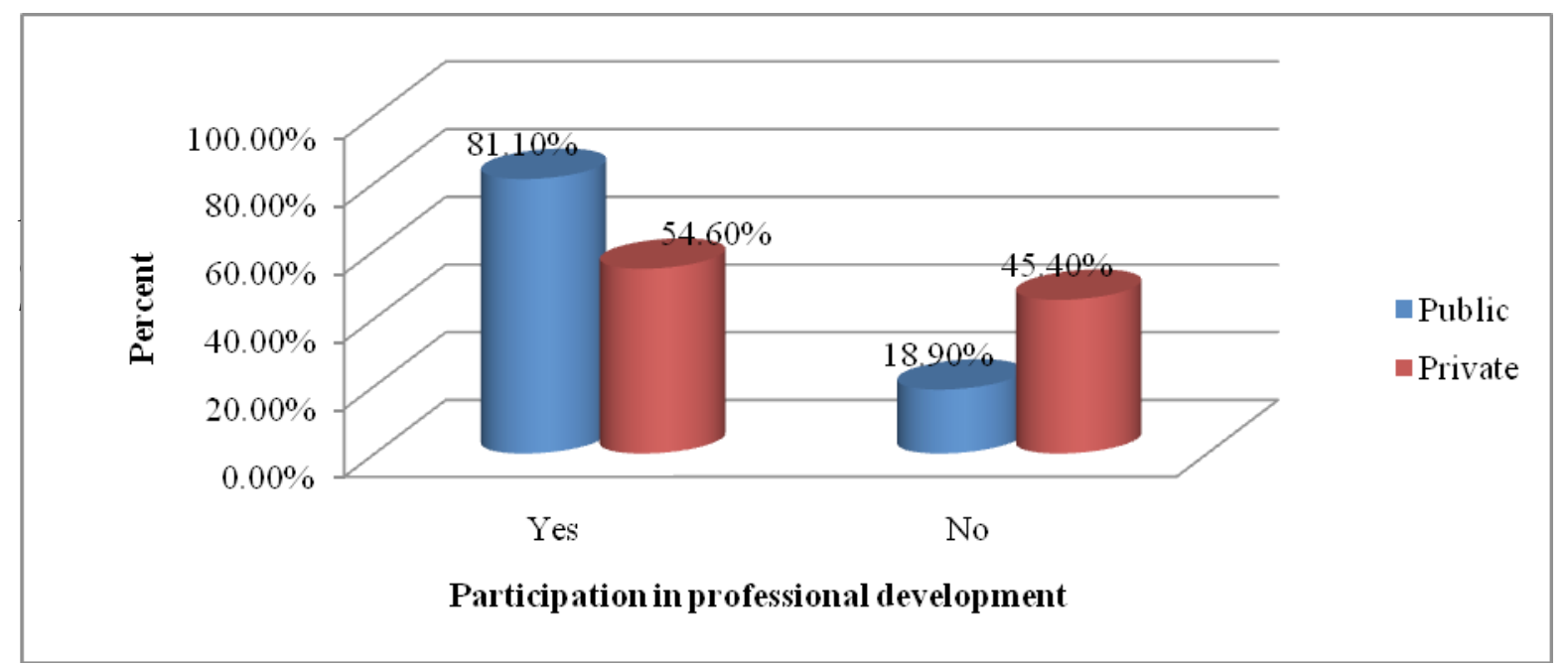

\section{Figure 1: Teacher participation in professional development activities}

Figure 1 shows that $81(81.1 \%)$ of the teachers in public schools had been engaged in some form of professional development in their teaching career compared to 38 (54\%) of those from private schools indicated the same. On the other hand, 33 (46.4\%) of teachers in private schools indicated they had not been engaged in professional development activities in their career compared to 18 (18.9\%) from public schools. This study therefore established that more teachers in public schools had engaged in professional development activities that comprised acquisition of degrees and diplomas, attendance to SMASE and other in-service course compared to their counterparts in private schools. This finding confirms what the OECD (2013) study found that on average teachers in public schools engaged more in professional development activities than their private school counterparts, a difference that is not statistically significant. OECD (2005) survey also reported that $89 \%$ of lower secondary teachers had engaged in professional development. Teachers who reported that they did not engage in any form of professional development cited lack of information on professional development opportunities, limited resources and time as factors that hindered them from engaging in these activities. 


\section{Teachers Academic Qualifications}

In this study, professional development comprised teacher academic achievement and attendance to in-service training courses.

\section{Teachers' academic qualifications progress}

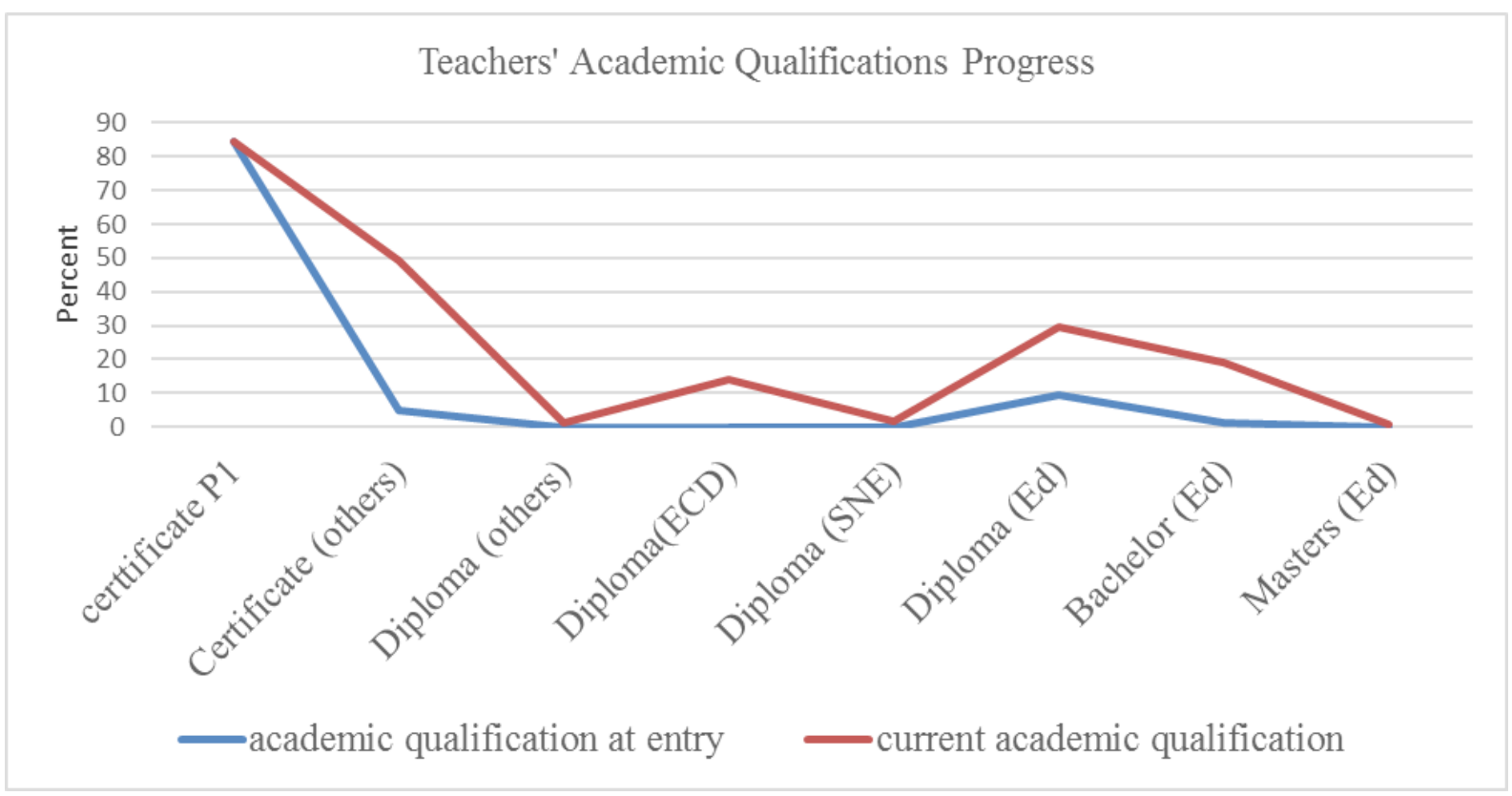

\section{Figure 3: Teachers' academic qualifications progress}

The study established that $76(44.7 \%)$ of the teachers had obtained certificates in guidance and counselling and other courses. Figure 3 further shows that 34 (20\%) had diploma in education as their current academic and 30 (17.6\%) had attained Bachelor's degrees. The finding also showed that more 58 (58.6\%) teachers in public schools had acquired Bachelor's degrees and Diplomas compared to $35(49.8 \%)$ teachers in private schools. The number of those who had acquired Master's degrees was minimal. Buddin's and Gema's (2009) study in Los Angeles elementary schools found a relationship between teacher academic qualifications and achievement. However, Kimani et al (2013) established that teachers in Nyandarua County, Kenya, had acquired higher academic qualification but the additional professional qualifications above the first degree did not lead to improved competence of teaching and learner achievement at the secondary school level. Rivkin et al (2005) had also earlier found no evidence that a master's degree improves achievement at secondary school level. Clotfelter, Ladd, and Vigdor (2008) concluded that teachers in early grades who got Master's degrees after five years of teaching had a negative effect on learner achievement.

The study further sought to find out the effects of teacher academic qualifications after pre service training and attendance to in-service courses on KCPE achievement. Teacher academic progress was computed by having two groups of teachers that is, those who had improved their academic qualifications and those who had not. 
Table 1: Teacher Attendance to in-service courses

\begin{tabular}{llllll}
\hline Attendance & & Yes & \multicolumn{3}{l}{ No } \\
\hline \multirow{2}{*}{ School Type } & & $\mathrm{N}$ & $\%$ & $\mathrm{~N}$ & $\%$ \\
& Public & 83 & 80.5 & 20 & 19.4 \\
& Private & 32 & 47.7 & 35 & 52.4 \\
\hline Total & & 115 & 67.7 & 55 & 32.3 \\
\hline
\end{tabular}

Table 1 shows $115(67.7 \%)$ of the teachers in Kirinyaga County had attended in-service training compared to $55(32.3 \%)$ who indicated that they had not attended any in-service courses. Table 4.9 further reveals that majority $83(80.5 \%)$ of the teachers who had attended in-service courses were from public schools compared to $32(47.7 \%)$ were from private schools. This showed that more public school teachers had attended in-service training compared to those in private schools. The result showed that majority of the respondents had attended in-service training. This finding is contrary to Essel, Badu-Boateng \& Saah (2009) study on in-service training in Ghana who found that only $40 \%$ of their respondents had attended in-service training in the last three years. They also found out that $24 \%$ of the respondents had not attended in-service training 12 years prior to their research. They found a negative relationship -0.023 between teacher in-service training and KCPE achievement.

During the focus group discussions, teachers in private schools who had not attended in-service courses indicated that it was difficult to be granted permission by the school managers to attend to trainings during the school hours. Others reported that the schools were not willing to commit resources to facilitate them to attend in-service training courses.

A study by Feng and Sass (2010) found that teacher in-service professional development has little effects on teacher ability to increase learner achievement. However, a study carried out in Pakistan found a positive impact of in-service training programs on the performance of teachers (Junejo, Sarwar \& Ahmed, 2017).

\section{Forms of in-service Training Attended}

Teachers were asked to indicate the forms of in-service course that they had attended. The findingare shown in figure 3

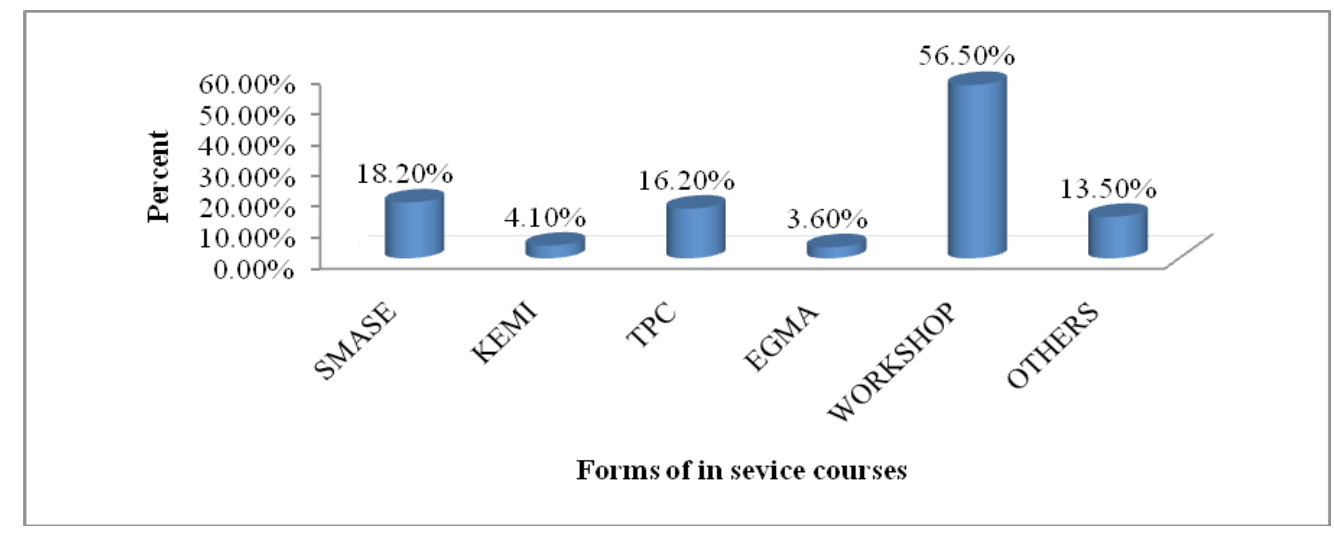

\section{Figure 3: Forms of in-service courses}

The findings in figure 4 indicate that teachers had participated in different forms of in-service courses. 
Figure 3 shows that majority $96(56.5 \%)$ of the teachers had participated mainly in workshops and seminars while $18.2 \%$ had attended Strengthening Mathematics and Science Education (SMASE) program. Teachers who had been engaged in Kenya Education Management Institute (KEMI) courses were only $7(4.1 \%)$ yet this is an educational institution that offers training opportunities to teachers and school managers.

One off seminars and workshops facilitators often attempt to change teachers' beliefs and attitudes. The expectations were that once teachers changed their beliefs and practices, their classroom practices and behaviors would also change (Clarke \& Hollingsworth, 2002). According to Fullan (2009), only $10 \%$ to $20 \%$ of American teachers engage in meaningful professional development while $90 \%$ of them participate in professional development consisting mainly of one day shortterm workshops and conferences. Fullan (1991) had earlier noted that nothing has promised so much and has been so frustrating and wasteful as the thousands of workshops and conferences that lead to no significant change in practice when the teachers return to their classroom. Hunzincker (2011) asserts that professional development through workshop is often ineffective in meeting teacher needs.

The study sought to establish the duration of the different in-service training programs that the teachers indicated they had attended. The findings are presented in table 2

Table 2: Duration of in-service courses

\begin{tabular}{lrrrrrrrrrr}
\hline \multirow{2}{*}{ Duration } & \multicolumn{2}{c}{$\mathbf{1}$ day } & \multicolumn{2}{c}{$\mathbf{2 - 5}$ days } & \multicolumn{1}{c}{$\mathbf{1 - 3}$ weeks } & \multicolumn{1}{c}{$\mathbf{1 - 2}$ month } & \multicolumn{2}{c}{ More than 2 months } \\
\cline { 2 - 12 } & \multicolumn{1}{c}{$\mathrm{n}$} & \multicolumn{1}{c}{$\%$} & \multicolumn{1}{c}{$\boldsymbol{N}$} & $\mathrm{N}$ & \multicolumn{1}{c}{$\%$} & $\mathrm{n}$ & \multicolumn{1}{c}{$\%$} & $\mathrm{~N}$ & $\%$ \\
\hline SMASE & 12 & 28.6 & 3 & 7.1 & 9 & 21.4 & 2 & 4.8 & 16 & 38.1 \\
KEMI & 0 & 0.0 & 3 & 37.5 & 0 & 0.0 & 1 & 12.5 & 4 & 50.0 \\
TPC & 0 & 0.0 & 13 & 44.8 & 15 & 51.7 & 1 & 3.4 & 0 & 0.0 \\
EGMA & 0 & 0.0 & 5 & 83.3 & 1 & 16.7 & 0 & 0.0 & 0 & 0.0 \\
workshop/seminar & 87 & 76.3 & 17 & 14.9 & 6 & 5.3 & 1 & 0.9 & 3 & 2.6 \\
Others & 0 & 0.0 & 1 & 7.7 & 2 & 15.4 & 1 & 7.7 & 9 & 69.2 \\
\hline
\end{tabular}

The findings in table 2 showed that majority 87 (76.3\%) of the teachers were involved in workshops and seminars, which had durations of one day. Most of the professional development programs that teachers engaged in ranged between durations of one day to three weeks. Penuel, Fishman, Yamaguchi, \& Gallagher, (2007) opine that workshops continue to be the common form of professional development but they are often short term and removed in time from everyday practice of the teachers.

Duration is defined as "both the number of contact hours of professional development, and the length of time over which engagement in the activity spans (Hochberg \& Desimone, 2010). Supovitz and Turner (2000) determined that the total number of contact hours of professional development had a positive association with teachers' outcomes such as: attitude, preparedness, and teaching practice. Yoon et al (2007) found that studies that provided sufficient contact hours of professional development ranging between 30 to 100 hours with an average of 49 hours showed a statistically significant and positive effects on student achievement gains. On the other hand, professional development with duration of 5 to 14 hours had no effects on student learning. 
This study found that majority of the teachers had attended professional development courses that were less than 30 hours. This was an indication that the courses were short term and likely to have minimal impact as supported by the literature reviewed. This finding concurs with Birman, et.al. (2007) who established that only $7 \%$ of elementary school teachers participated in Mathematics professional development for more than one day in a year. For professional development to be effective, it should be continuous and long term. In Kenya, a report by TSC highlighted that the long term accredited programs that teachers were pursuing were having little impact on their professional development (Otieno, 2009). Activities that extend over time are more likely to allow teachers more time to try out new practices in the classroom and obtain feedback on their teaching (Girvan et al 2016). Effective professional development should be sustained, on-going, in-depth and with active engagement by the professional. Short-term, one-short programs are said to be ineffective. Desimone and Garet (2015) established that 20-100 hours of professional development over a period of six months would change teachers' practice.

Teachers were asked to indicate the number of in-service courses they had attended in given periods of time. The results are shown in table 5

Table 3: Frequency of attendance to in-service courses

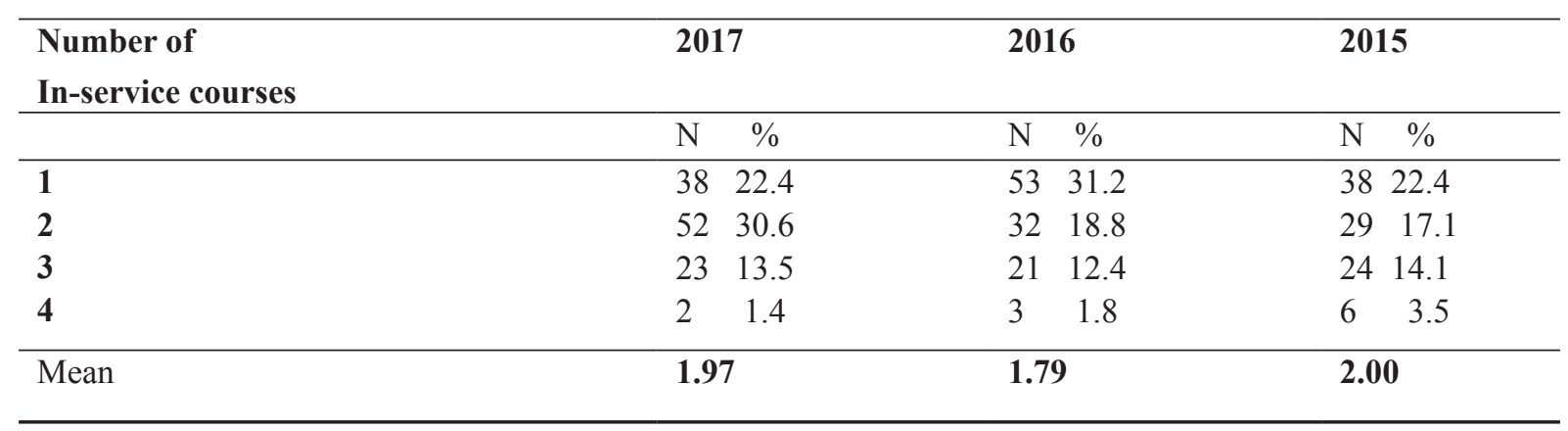

Table 3 shows that the frequency of teachers' attendance to in-service courses was on average twice per year. The finding reveals that the average attendance in 2017 was 1.97; in 20161.79 and in 2015 it was 2. However, it is important to note that there is an improvement in frequency of attendance to in-service courses in 2017 compared to 2016. For example, those who attended at least two courses in 2017 increased to 52 (30.6\%) compared to $32(18.8 \%)$ in 2016. Those who had attended four in-service courses per year were minimal across the years: $2(1.4 \%)$ in 2017, 3 $(1.4 \%)$ in 2016 and $6(3.5 \%)$ in 2015 . The number of in-service training that a teacher attended per year was low as it shows majority attended a course after six to four months. The analysis of attendance per year was important because the KCPE achievement in consideration was also for the subject mean for 2015, 2016 and 2017. A study by Ampofo (2017) on teachers in senior high schools in central region, Ghana, found that teacher in-service training programs were organized at least once every academic year.

Hochberg and Desimone (2010) concluded that a duration of professional development comprises the number of contact hours as well as the frequency of attendance. According to Desimone (2009), for any professional development program to be effective, it must be continuous and long term. This shows that the frequency of teacher professional experiences was critical if the program was 
going to have meaningful impact. Teachers' learning takes place over time rather than in isolated moments in time. Active learning requires opportunities to link previous knowledge with new knowledge. This was not possible with low frequency of training. This means that teachers required frequent opportunities to focus on improving their practice especially in their everyday life and activities in school. There is need therefore for teachers to continuously engage in professional development activities.

\section{Effects of in-service training on KCPE Achievement}

Inferential statistics specifically the t-test was used to measure the effects of teacher academic qualifications and attendance to in-service courses i.e. forms, duration and frequency on KCPE achievement

Table 4: Group statistics for professional development and KCPE achievement

\begin{tabular}{llccrc}
\hline \multicolumn{7}{c}{ Group Statistics } \\
\hline & professional development & N & Mean & $\begin{array}{c}\text { Std. } \\
\text { Deviation }\end{array}$ & $\begin{array}{c}\text { Std. Error } \\
\text { Mean }\end{array}$ \\
\hline $\begin{array}{l}\text { KCPE } \\
\text { achievement }\end{array}$ & Yes & & & 6.135878 & .587711 \\
& No & 109 & 56.07384 & & \\
& & 60 & 56.31109 & 6.833626 & .882217 \\
\hline
\end{tabular}

The statistic in table 4 gave a mean score of 56.07 with a standard deviation of 6.13 for a total $n$ of 109 teachers who had improved academic qualifications and attendance to in-service courses. Further, the teachers with no formal training had a mean score of 56.31 with a standard deviation of 6.83 for a total $n$ of 60 teachers. It was observed that there was a slight difference in mean for teachers with improved academic qualifications and attendance to in-service courses and those who had not. To test whether the observed difference in mean was statistically significant, an independent sample t-test was carried out.

Table 5: Independent Samples Test on effects of in-service training on KCPE achievement

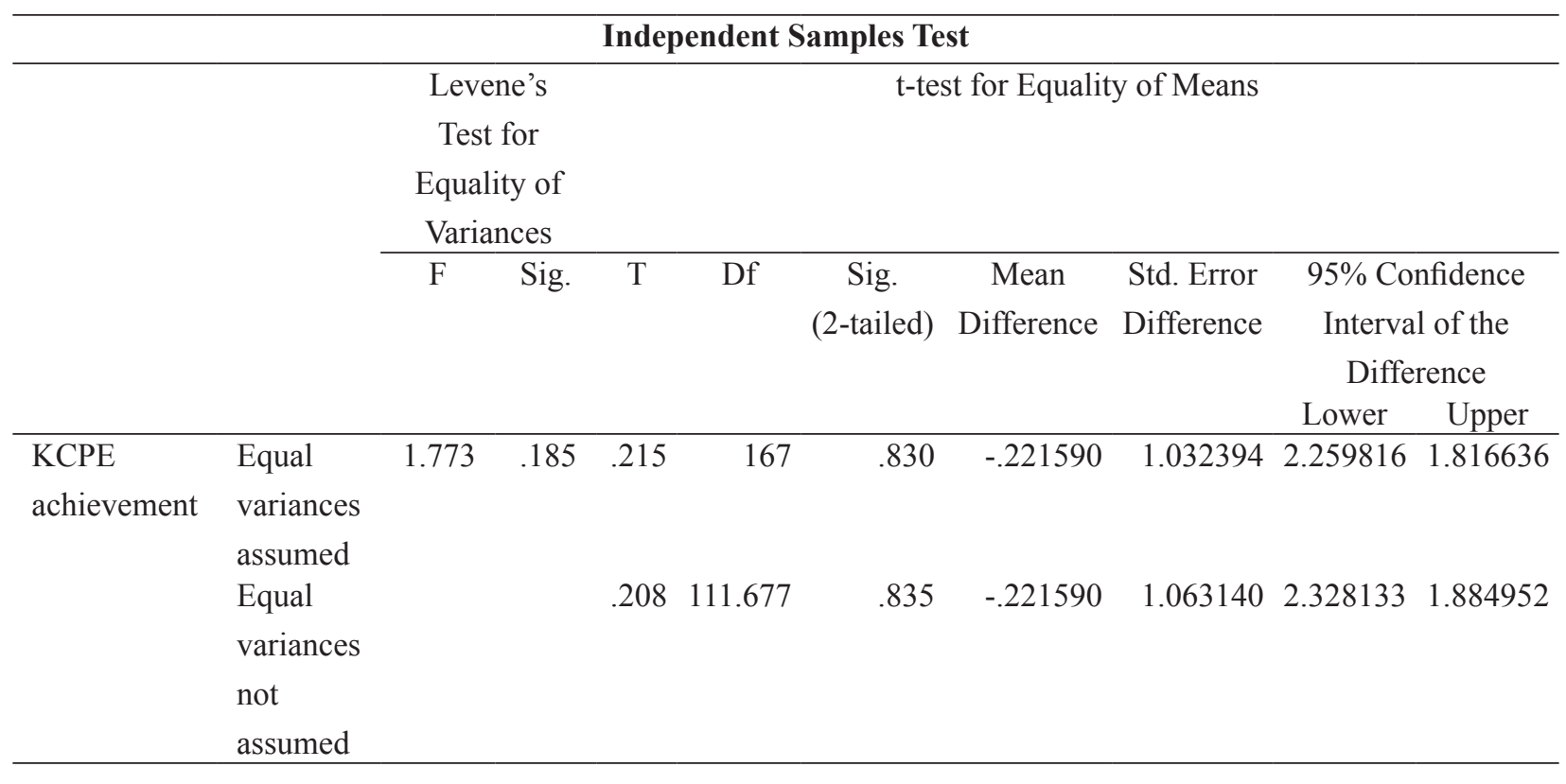


This study established that the effects of in-service training on KCPE achievement were statistically insignificant since the $\mathrm{p}$ value $(0.830)$ was greater than 0.05 . This implies that formal training (academic qualifications and attendance to in-service courses) was not a factor affecting KCPE achievement in Kirinyaga County. This means that the study fails to reject the null hypothesis that 'there is no significant effects of teacher formal training on KCPE achievement' and therefore adopts the hypothesis. The calculated Cohen's $\mathrm{d}$ was 0.03 which is below 0.2 and interpreted as a very small effects size.

\section{Conclusion}

The study concludes that teacher improved academic qualifications and attendance to in-service training had statistically insignificant effects on learner achievement. Further, teachers engaged in in-service courses that were short term and infrequent in the form of workshops and seminars.

\section{Recommendations}

Teachers need to be engaged in a variety of continuous, collaborative job-embedded professional development activities in addition to academic advancement and in-service courses outside the schools.

The study recommends establishment of school infrastructure to support daily collaborative teacher professional development activities at the school level.

\section{References}

Aaronson, D., Barrow, L., \& Sanders, W. (2003). Teachers and student achievement in the Chicago public high schools (Working Paper No. 2002-28). Chicago: Federal Reserve Bank of Chicago

Ampofo S (2017). Effects of school heads' instructional supervision practices on teacher role performance in selected public senior high schools, central region, Ghana; unpublished $\mathrm{PhD}$ thesis, Kenyatta University

Ball, D. L., \& Cohen, D. K. (1999). Developing practices, developing practitioners: Toward a practice-based theory of professional development. In G. Sykes \& L. Darling-Hammonds (Eds.), Teaching as the learning profession: Handbook of policy and practice (pp. 30-32). San Francisco, CA: Jossey-Bass.

Betts, J. R., Zau, A., \& Rice, L. (2003). Determinants of student achievement: New evidence from San Diego (pp. 1-5821). San Francisco: Public Policy Institute of California.

Bezzina, C. (2001). The Professional Development of Head teachers in Malta: trends and developments, International Journal of Educational Management, 15(3), pp. 138-144

Birman, B., Le Floch, K. C., Klekotka, A., Ludwig, M., Taylor, J., Walters, K., Yoon, K. (2007). State and local implementation of the No Child Left Behind Act: Vol. 2. Teacher quality under NCLB: Interim report. Washington, DC: U.S. Department of Education; Office of Planning, Evaluation and Policy Development; Policy and Program Studies Service.

Boyd D. J., Grossman P. L., Lankford H., Loeb S., Wyckoff J., (2009). Teacher Preparation and Student Achievement. Educational Evaluation and Policy Analysis, vol. 31, 4: pp. 416440., First Published December 1, 2009. 
Buddin R, Zamarro G (2009). Teacher qualifications and student achievement in urban elementary schools. Journal of Urban Economics, 66(2): 103-115.

Clarke, D., \& Hollingsworth, H. (2002). Elaborating a model of teacher professional growth. Teaching and Teacher Education, 18, 947-967.

Clotfeler, C.T., Ladd, H.F., \&Vigdor, J.L. (2006). Teacher-Student matching and the assessment of teacher effectiveness (NBER, Working paper No. 11936). Cambridge, MA: National Bureau of Economic Research

Cohen, D. K., \& Hill, H. C. (2000). Instructional policy and classroom performance: The

Darling-Hammond, L. (2000). Teacher quality and student achievement: A review of state policy evidence. Education Policy Analysis Archives, 8(1).Retrieved from http://olam.ed.asu.edu/ epaa/v8nl/ retrieved on 24/6/2017

Darling-Hammond, L. (2009). President Obama and education: The possibility for dramatic improvements in teaching and learning. Harvard Educational Review, 79(2), pp. 210-223.

Darling-Hammond, L., Wei, R. C., Andree, A., Richardson, N., \& Orphanos, S. (2009). Professional learning in the learning profession: A status report on teacher professional development in the United States and abroad. Washington, DC: National Staff Development Council

Darling-Hammond, L., Hyler, M. E., Gardner, M. (2017). Effective Teacher Professional Development. Palo Alto, CA: Learning Policy Institute

Desimone, L. M. (2009). "Improving Impact Studies of Teachers' Professional Development: toward Better Conceptualizations and Measures." Educational Researcher 38 (3):181-199.

Desimone Laura M. \& Garet Michael S. (2015). Best Practices in Teachers' Professional Development in the United States, Psychology, Society, \& Education, 2015. Vol. 7(3), pp. 252-263

Essel, R. Babu, E., Owusu-Boateng, W \&Saah, A.A. (2009). In -service training: An essential element in the professional development of teachers. Malaysian Journal of Distance education 11(2), 55-64

Feiman-Nemser, Sharon (2001). From Preparation to Practice: Designing a Continuum to Strengthen and Sustain Teaching. Teachers College Record, v103 n6 p1013-55 Dec 2001

Feng L., and Sass T., (2010). What makes special-education teachers special? Teacher training and achievement of students with disabilities Economics of Education Review 36:122 134 . DOI: $10.1016 /$ j.econedurev.2013.06.006

Fullan, M. (1990). 'Staff development, innovation and institutional development. in Joyce. B. (Ed) Changing School Culture Through Staff Development (pp. 3-25). Alexandria, VA: Association for Supervision and Curriculum Development.

Fullan, M. (2007). The new meaning of educational change (4th ed.). New York: Teachers College Press mathematics reform in California. Teachers College Record, 102, 294-343.

Fullan, M. (2010). All systems go: The change imperative for whole school reform. Thousand Oaks, CA: Corwin Press

Global Education Monitoring Report Team (2014). Teaching and learning: achieving quality for all; EFA global monitoring report, 2013-2014; summary. Programme \& meeting document

Goldhaber, D. D., \& Brewer, D. J. (2000). Does teacher certification matter? High school 
teacher certification status and student achievement. Educational evaluation and policy analysis, 22(2), 129-145

Girvan, C., Conneeley, C., \& Tangney, B. (2016). Extending experiential learning in teacher professional development. Teaching and Teacher Education, 58, 129-139.

Guskey, T. R. (2000). Evaluating professional development. Thousand Oaks, CA: Corwin Press.

Hanushek, E. A., Kain, J. F., O’Brien, D. M., \&Rivkin, S. G. (2005). The market for teacher quality (No. w11154). National Bureau of Economic Research.

Harris, Douglas N. and Tim R. Sass. 2007. "What Makes for a Good Teacher and Who Can Tell?” Unpublished. Tallahassee: Florida State University

Harris, D. N., \& Sass, T. R. (2011). Teacher training, teacher quality and student achievement. Journal of public economics, 95(7-8), 798-812

Hochberg, E. D., \&Desimone, L. M. (2010). Professional development in the accountability context: Building capacity to achieve standards. Educational psychologist, 45(2), 89-106.

Hunzicker, J. (2011). Effective professional development for teachers: a checklist. Professional Development in Education 37(2). doi:10.1080/19415257.2010.523955

Junejo, A. M., Sarwar, M., \& Ahmed R., (2017). Impact of In-Service Training on Performance of Teachers a Case of STEVTA Karachi Region, International Journal of Experiential Learning\& Case Studies Vol 2

Joyce, B. \& Showers, B. (2002). Student achievement through professional development. InB. Joyce \& B. Showers (Eds.), Designing training and peer coaching: Our need for learning. Alexandria, VA: ASCD

Kimani G. N., Kara A. M., \& Njagi L. W., (2013). Teacher Factors Influencing Students' Academic Achievement in Secondary Schools in Nyandarua County, Kenya. International Journal of Education and Research Vol. 1 No. 3 March 2013

Kukla-Acevedo S (2009) Do teacher characteristics matter? New results on the effects of teacher preparedness on student achievement, retrieved on 27 November, 2018 from http://doi. org/10.1016/j.econedurev 2007.10.007

Musau L., M. \& Migosi J. Instructional resources and girls' academic achievement in Science, Mathematics and Technology subjects. International journal of Education Economics and Development, 2014;5(2):140-151

No Child Left Behind Act of 2001, Pub. L. No. 107-110, x 115, Stat. 1425 (2002)

OECD (2005), Teachers Matter, OECD, Paris.

Otieno, S., (2009), Teachers Pursuing the Wrong Courses for Promotion, The Standard on Sunday, Nairobi, Standard Ltd, pg. 24 Col 1.

Parise, L. M., \& Spillane, J. P. (2010). Teacher learning and instructional change: How formal and on-the-job learning opportunities predict change in elementary school teachers' practice. The elementary school journal, 110(3), 323-346.

Penuel, W.R, Fishman, B.J., Yamaguchi, R., \& Gallagher, L.P. (2007). What makes professional development effective? Strategies that foster curriculum implementation. American Educational Research Journal, 44(4), 921-958

.Republic of Kenya (2010). The Kenya Constitution. Government printer. Nairobi 
Rivkin, S.G., Hanushek E.A., and Kain J.F., (2005), 'Teachers, Schools and Academic Achievement,' Econometrica. vol.73 No. 2, pp 417-458.

Rowan, B., Correnti, R., \& Miller, R. J. (2002). What large-scale, survey research tells us about teacher effects on student achievement: Insights from the prospectus study of elementary schools.

Supovitz, J.A. (2002). Developing Communities of Instructional Practice. Teachers College Record, $104,2,127-146$

Teaching and Learning International Survey. (2008). Creating effective teaching and learning Environment first results from TALIS. Retrieved from https:// www.oecd.org/edu/ school/43023606.pdf

Teachers Service Commission (TSC) Act, 2012. Government printer, Nairobi

Teachers Service Commission (2018) Career progression Guidelines, TSC circular no:7/2018.

Wenglinsky, H. (2000). How teaching matters: Bringing the classroom back into discussions of teacher quality (Policy Information Center Report). Princeton, NJ: Educational Testing Service.

Wenglinsky, H. (2002). How schools matter: The link between teacher classroom practices and student academic performance. Education Policy Analysis Archives, 10(12), 1-31. Retrieved March 27, 2012, from epaa.asu.edu/epaa/v10n12.

World Bank (2010) Responding to the Twin Challenges: Teachers, Teaching and Technology. Retrieved on $15^{\text {th }}$ October 2015 from: http://siteresource, worldbank.org/ Education/ Resource/278200-1099079877269

Yoon, K. S., Duncan, T., Lee, S. W. Y., Scarloss, B., \& Shapley, K. (2007). Reviewing the evidence on how teacher professional development affects student achievement. (Issues \& Answers Report, REL 2007- No.033). Washington, DC. 